\title{
Integrated Management of Downy Mildew on Slicing Cucumber With Fungicides and Host Resistance But Not Trellising
}

\author{
Anthony P. Keinath ${ }^{\dagger}$ \\ Department of Plant and Environmental Sciences, Coastal Research and Education Center, Clemson University, Charleston, SC \\ 29414
}

\begin{abstract}
The objective of this study was to evaluate fungicide applications, host resistance, and trellising, alone and in combination, as management practices for downy mildew on slicing cucumber. A split-split plot experimental design was used with three and four replications in spring and fall 2017, respectively. The whole-plot treatment was fungicide, four applications of chlorothalonil (Bravo Weather Stik 6SC) alternated with three applications of cyazofamid (Ranman 400SC), or water. Split plots were nontrellised or trellised with four strings supported by stakes. Splitsplit plots were cultivar Bristol, which is intermediately resistant to downy mildew, or cultivar Speedway, which is susceptible to downy mildew with similar parentage as Bristol. In both seasons, area under the disease progress curve (AUDPC) values were lower with fungicides than

differ between the two cultivars with water. The mean AUDPC for trellised plants (376.2) was lower than for nontrellised plants $(434.0 ; P=$ 0.007). Fungicide applications increased marketable and total fruit weights in both seasons $(P \leq 0.0002)$. Marketable weight with fungicides was almost double (93\% greater) the marketable weight with water. Marketable weight was 55\% greater for Bristol than for Speedway in spring, but yields did not differ between cultivars in fall (season-bycultivar interaction, $P \leq 0.0003$ ). Because trellising had no effect on marketable yields $(P=0.11)$, trellising is not recommended for managing downy mildew on slicing cucumber. Of the three management techniques examined, fungicides had the largest effects on disease and yields, followed by cultivar resistance.
\end{abstract} water for both cultivars. In the spring, AUDPC for Bristol was lower than for Speedway regardless of fungicide treatment. In the fall, Bristol had a lower AUDPC than Speedway with fungicides, but the AUDPC did not
Keywords: cultural and biological practices, economic impacts, oomycetes, vegetables, yield loss
One principle of integrated pest management (IPM) is that an IPM system for a given crop should include "a combination of techniques such as biological control, habitat manipulation, modification of cultural practices, and use of resistant varieties" (University of California Statewide Integrated Pest Management Program 2013). When management practices are used in combination, the effects can be additive, synergistic, or antagonistic (Ritchie et al. 2018). When effects are additive, the level of control is approximately the sum of the control achieved when each practice is applied separately. Additive effects are revealed in analysis of variance by significant main effects of two treatments without an interaction between them. When effects are synergistic, the benefits of combining two practices are more effective than predicted, based on the effects of the two management techniques applied together, and there is a significant interaction between the two treatments. Applying protectant fungicides, such as mancozeb, to potato cultivars partially resistant to late blight is a classic example of additive effects of control measures on disease development (Fry 1978). For cucurbit downy mildew, a destructive disease caused by the oomycete pathogen Pseudoperonospora cubensis (Berk. \& M.A. Curtis) Rostovzev, both additive and synergistic effects of partial resistance and fungicides have been reported on disease (Call et al. 2013; Cooper et al. 2012; Holdsworth and Mazourek 2014; Schoenhals and Jasinski 2016).

Prior to 2004, host resistance in slicing and pickling cucumber (Cucumis sativus L.) derived from Plant Introduction (PI) 197087 was the main disease management method for downy mildew caused

${ }^{\dagger}$ Corresponding author: A. P. Keinath; tknth@clemson.edu

Funding: This material is based on work supported by the U.S. Department of Agriculture National Institute of Food and Agriculture under project number SC-1700536. Technical Contribution No. 6725 of the Clemson University Experiment Station.

The author(s) declare no conflict of interest.

Accepted for publication 28 April 2019.

(C) 2019 The American Phytopathological Society by mating type A2 of $P$. cubensis (Holmes et al. 2015; Sitterly 1972). Mating type A1 of $P$. cubensis was detected in the United States in 2004 in North Carolina on a cultivar of pickling cucumber that was resistant to mating type A2 (Holmes et al. 2015; Thomas et al. 2017a). Resistance to mating type A1 was identified in PI 197088 in 2017 (Wang et al. 2018). The resistance in PI 197088 is highly effective at reducing foliar severity of downy mildew and preventing yield losses, even without fungicide applications (Call et al. 2013). However, the level of resistance in currently available, partially resistant cultivars often is not sufficient to prevent substantial yield loss, including complete crop failure, if fungicides are not applied (Cooper et al. 2012; Holdsworth and Mazourek 2014; McGrath et al. 2018).

In the southeastern United States, cucumbers are grown in spring and fall (Aerts and Mossler 2003; Kemble et al. 2019). Although downy mildew is a threat in both seasons, severity is often greater in the fall than in the spring, owing to longer leaf wetness periods from dew and a constantly present source of inoculum (Neufeld and Ojiambo 2012). Because $P$. cubensis overwinters south of $30^{\circ} \mathrm{N}$ latitude, early spring crops grown north of this latitude may not be exposed to $P$. cubensis sporangia until later in the season, depending on how soon sporangia are dispersed and transported from source plants on which P. cubensis overwinters (Holmes et al. 2015). Foliage of cucumber and other cucurbits can be infected at any stage of host development. Symptoms on cucumber are chlorotic, angular leaf lesions that become necrotic. Signs of the pathogen are hyaline sporangiophores and purplish sporangia produced on the adaxial leaf side (Hausbeck 2017).

Trellising cucumbers has been recommended as a cultural method to manage downy mildew (Colucci and Holmes 2010). Leaf wetness periods are assumed to be shorter on trellised plants, or leaves on trellised plants receive more solar radiation than plants in flat-bed culture, which reduces sporangia viability (Kanetis et al. 2010; Neufeld and Ojiambo 2012). In two experiments in Ohio, however, trellising had no effect on final severity or area under the disease progress curve (AUDPC) values calculated from the severity of downy mildew on slicing cucumber cultivar Dasher II, an older cultivar resistant to mating type A2 but susceptible to mating type A1 of $P$. cubensis. In one experiment, however, the marketable weight and 
weight of cull fruit was greater on trellised plants than nontrellised plants (Baysal-Gurel et al. 2014, 2015). Trellising has not yet been evaluated on field-grown cucumber in the southeastern United States, nor has the combination of trellising with cultivars partially resistant to mating type A1 been examined.

Another primary benefit of implementing IPM practices is a reduction in reliance on pesticides as a sole measure of pest management. $P$. cubensis, an organism with a high risk for developing insensitivity to fungicides, is insensitive to quinone outside inhibitors, mandipropamid, fluopicolide, and propamocarb (Keinath 2016; Olaya et al. 2009; Thomas et al. 2018). As of 2018, cyazofamid (Fungicide Resistance Action Committee [FRAC] code 21) and oxathiapiprolin (FRAC code 49) were used widely to manage downy mildew on cucumber because of their consistent efficacy and short preharvest interval of 0 days (Kemble et al. 2019). For cucurbit downy mildew, integrated management may lead to less exposure of the pathogen to fungicides, which is a fundamental principle to delay the development of fungicide resistance (Brent and Holloman 2007). In Virginia, the AUDPC for the cucumber cultivar Tasty Green, which is partially resistant to downy mildew, did not differ when this cultivar was sprayed twice or four times with downy mildew fungicides (Cooper et al. 2012). In this study, fungicide exposure was cut by half, since $P$. cubensis was exposed to only one dose of each of two fungicides instead of two doses.

The objectives of the current study were to evaluate the effects of fungicide applications, host resistance, and trellising, alone and in four combinations, on the development of downy mildew and yields of slicing cucumber to determine which management practices contributed to disease reduction and yield increase compared with the no-management control treatment.

\section{Materials and Methods}

The experiments were done in the spring and fall of 2017 at the Clemson University Coastal Research and Education Center in Charleston, South Carolina (32.47304 N; 80.41116 W). The study was replicated in two different fields of Yonges loamy fine sand with a $\mathrm{pH}$ of 6.4 in the spring and 5.9 in the fall. The fields used in spring and fall were previously cropped to rye (Secale cereale 'Abruzzi') and crimson clover (Trifolium incarnatum), respectively. On 10 May and 8 August 2017, cucumber was direct seeded into 0.9-mwide raised beds on 1.8-m centers covered with black polyethylene mulch in the spring and white-on-black polyethylene mulch in the fall. Plots were single rows oriented north to south, $4.6 \mathrm{~m}$ long with seven plants spaced $0.6 \mathrm{~m}$ apart. Plots were separated within rows by 4.6 or $3.1 \mathrm{~m}$ of nonplanted space in spring and fall, respectively.

Treatments were arranged in a split-split plot experimental design with three and four replications in spring and fall, respectively. The whole-plot treatment was fungicide, chlorothalonil (Bravo Weather Stik 6SC; Syngenta, Greensboro, NC) at $1.68 \mathrm{~kg} / \mathrm{ha}$ alternated weekly with cyazofamid (Ranman 400SC; FMC Corp., Philadelphia, $\mathrm{PA})$ at $80 \mathrm{~g} / \mathrm{ha}$. Chlorothalonil was applied four times, and cyazofamid was applied three times each season. The control treatment was sprayed with water. Fungicides and water were applied with a $\mathrm{CO}_{2^{-}}$ pressurized backpack sprayer calibrated to deliver 430 liters/ha at $414 \mathrm{kPa}$ with a $0.9-\mathrm{m}$ boom and three TeeJet TX 26 nozzles (Spraying Systems Co., Wheaton, IL), with an orifice size of $2.35 \mathrm{~cm}$, spaced $46 \mathrm{~cm}$ apart. The split-plot treatment was trellised, consisting of four evenly spaced lines of polypropylene tomato twine held in place by 2 -cm-diamter, 1-m-long, round, wooden tomato stakes placed $1.2 \mathrm{~m}$ apart within the plot, or nontrellised, standard raised bed culture. Split-split plots were the cucumber cultivars Bristol, which is intermediately resistant to downy mildew, or Speedway, which is susceptible to downy mildew with similar parentage as Bristol (Bayer Crop Science, St. Louis, MO). Estimated days to harvest were 50 to 55 days for Bristol and 56 to 60 days for Speedway. Fungicide was assigned to whole plots to facilitate applications, and trellising was assigned to split plots to minimize any effects of shading on other treatments.

In both experiments, mefenoxam was applied through the drip tape, 2 to 3 days after seeding, to prevent Pythium damping off. In the spring, ethalfluralin, halosulfuron, and sethoxydim were applied for weed control. Bifenthrin, chlorantraniliprole, and dinotefuran were used to manage insects, based on scouting observations. Cyflufenamid, metrafenone, cyprodinil-difenoconazole, and benzovindiflupyrdifenoconazole were applied to manage powdery mildew and gummy stem blight. In the fall, halosulfuron was applied for weed control. Thiamethoxam, dinotefuran, spriomesifen, chlorantraniliprole, bifenthrin, flupyradifuron, thiamethoxam, and Bacillus thuringiensis were applied to manage insects. Cyprodinil-difenoconazole and benzovindiflupyr-difenoconazole were rotated to manage gummy stem blight, and thiophanate was applied once to prevent anthracnose.

A Watchdog weather station model 2700 (Spectrum Technologies, Aurora, IL) was used to record hourly air temperatures, dew points, rainfall, relative humidity, leaf wetness with a LW2 leaf wetness sensor, and solar radiation with a Lightscout silicon pyranometer. The weather station was located within a trellised split plot from 22 June to 9 July and 22 September to 12 October 2017 and within a nontrellised split plot from 11 to 17 July 2017 . Within each plot, leaf wetness data were recorded every $15 \mathrm{~min}$ on both the east- and westfacing sides of both rows (split-split plots). Leaves were considered wet when the leaf wetness sensor recorded a value $\geq 2$, based on visual observations of condensation on the sensor and leaves (data not shown). Solar radiation was recorded on the east- and west-facing sides of one trellised row in the spring from 22 June to 9 July 2017. Weather data were summed over each 24-h period before analysis.

Severity of cucurbit downy mildew was rated on 16, 20, 23, 27, and 30 June and 5 and 10 July 2017 in the spring and on 6, 13, 20, 25, and 29 September and 4 October 2017 in the fall. Severity was estimated as the percentage of leaf area that was chlorotic or necrotic on a 0 to $100 \%$ scale in $5 \%$ increments plus $1 \%$ for trace amounts of disease. An additional rating of necrotic leaf area was done on 30 June and 4 October 2017. Left and right lengthwise halves of each plot, corresponding to east- and west-facing sides, were rated separately on all rating dates. Plots were harvested twice per week on 20, 23, 26, and 29 June and 3, 6, and 10 July 2017 in the spring and on 21, 26, and 28 September and 2, 5, and 10 October 2017 in the fall. All fruit $\geq 15 \mathrm{~cm}$ were harvested, sized, and graded according to U.S. Department of Agriculture (USDA) standards, counted, and weighed. Cucumber fruit were graded by fruit diameter and shape. U.S. Extra No. 1 fruit have a diameter $\leq 6 \mathrm{~cm}$ and length $\geq 15 \mathrm{~cm}$, U.S. No. 1 Large fruit have a diameter $>6 \mathrm{~cm}$ (no length specified), and U.S. No. 1 Small fruit have a diameter $\leq 5 \mathrm{~cm}$ (no length specified) (U.S. Department of Agriculture 2018). To convert yields per plot to yields per hectare, a plot length of $5.2 \mathrm{~m}$ was used to account for a lack of competition on the plants at the ends of the plots; this is equivalent to a $15 \%$ correction factor for cucumber yields as discussed by Wehner (2019).

Returns per hectare were calculated by multiplying the weight of fruit in each category by the price for that category at each harvest date and summing the values. Prices for each harvest date were obtained from the USDA Agricultural Marketing Service Specialty Crops Market News for cucumbers produced in South Carolina and sold at the terminal market in Columbia, South Carolina, except in the fall, Georgia was used as the source of medium-sized cucumbers. Prices for unwaxed small and medium cucumbers of "better than fair quality" were used for fruit graded as small and E1, respectively. The price for medium cucumbers also was used for fruit graded as large. Prices for waxed and fair quality fruit were used when other prices were not available. If the high and low prices differed, the mean was used. In the spring, prices per carton were $\$ 12.50$ and $\$ 18.00$ on 20 June 2017 for small and medium fruit, respectively; \$20 on 23 June 2017 for both sizes; and $\$ 18$ for the remaining harvest dates for both sizes of fruit. In the fall, prices for small and medium fruit declined gradually from $\$ 30$ and $\$ 23$ per carton, respectively, on 21 September 2017 to $\$ 18$ and \$12, respectively, on 10 October 2017.

Per hectare costs of seed, fungicides, trellising, and other inputs were obtained from various sources of information. Seed costs, with two seeds per planting hole spaced $0.6 \mathrm{~m}$ apart in the row, were $\$ 238$ 
and \$172 for Bristol and Speedway, respectively (Seedway, Hall, NY). Four applications of chlorothalonil cost $\$ 91$, three applications of cyazofamid cost $\$ 105$, and each application cost $\$ 4.26$ in labor and machine hours, for a total fungicide cost of $\$ 270$ (Clemson Cooperative Extension 2018). Cost of trellising included $\$ 896$ for stakes (one per $1.2 \mathrm{~m}$ ), $\$ 16$ for four strands of string, and $\$ 86$ for labor, for a total cost of $\$ 998$ (Sydorovych et al. 2012). Other input costs included polyethylene mulch at $\$ 819$, variable costs of $\$ 6,632$, fixed costs of \$576, and other costs of \$518 (Clemson Cooperative Extension 2018). Net return per hectare was calculated by subtracting input costs from returns.

Data were analyzed with a generalized linear mixed model analysis (SAS PROC GLIMMIX, version 9.4; SAS, Inc., Cary, NC) with a split-split-split-plot model, with season (whole plot), fungicide (subplot), trellising (subsubplot), cultivar (subsub-subplot), and all interactions as fixed effects. Random effects included block-by-season, fungicide within block-by-season, and trellis within block-byseason-by-fungicide. Before analysis, data were checked for normality with PROC UNIVARIATE and transformed when necessary. Disease severity data were transformed by calculating the arcsine of the square root, AUDPC values were transformed by calculating the base-ten logarithm, and fruit weights were not transformed. Based on a preliminary analysis, severity ratings on east and west sides of rows did not differ ( $F$-value not significant, $P=0.25)$, so ratings were averaged before further analysis. Leaf wetness and solar radiation on the east and west sides of trellised rows were compared in separate analyses for each season. Residuals from analyses of variance were plotted against the predicted mean with the RESIDUALPANEL option and examined for normality to judge model goodness of fit. Back-transformed least-squares means are shown in the tables. Multiple comparisons among treatment means were based on $t$ tests calculated with the PDIFF option in PROC MIXED.

Average maximum/minimum temperatures were $30.3 / 21.2$ and $32.6 / 23.1^{\circ} \mathrm{C}$ for June and July and $30.4 / 20.3$ and $26.6 / 15.4^{\circ} \mathrm{C}$ for September and October, respectively. Rainfall was 164.3 and $219.4 \mathrm{~mm}$ for June and July and 171.4 and $90.6 \mathrm{~mm}$ for September and October, respectively. Rainfall in July was $54 \mathrm{~mm}$ more than the 30-year normal (1981 to 2010), whereas rainfall was within the normal range (i.e., $<25 \mathrm{~mm}$ deviation) for the other months.

\section{Results}

Based on symptoms on differential cucurbit species and cultivars planted as part of the Cucurbit Downy Mildew-IPM-Pest Information Platform for Extension and Education, P. cubensis mating type A1 likely was present at the Coastal Research and Education Center in Charleston, South Carolina, in the spring and fall experiments, whereas mating type A2 likely was observed only in the fall (Ojiambo et al. 2011; Thomas et al. 2017b).

There was a significant interaction $(P<0.0001)$ between season and fungicide for final disease severity; however, the interaction resulted simply because disease was more severe in spring (76 to $82 \%$ ) than in fall (47 to $58 \%$ ) in the water-treated control for both cultivars. In the fungicide treatment, final disease severity did not differ between seasons with either cultivar (Tables 1 and 2). Thus, fungicides were effective in both seasons on both cultivars, regardless of trellising treatment. In addition, Bristol had lower final severity than Speedway across both seasons, fungicide treatments, and trellising treatments (cultivar main effect significant, $P<0.0001$ ). Severity ratings did not differ between trellised plants and plants grown without trellising for 12 of the 13 ratings across both seasons (data not shown) (trellis main effect not significant, $P=0.11$ ).

AUDPC values did not differ between seasons for any fungicide-cultivar treatment combination, as the main effect of season and all interactions with season were not significant $(P \geq 0.30)$ (Table 1). In both seasons and for both cultivars, AUDPC values were lower for fungicide treatments than water treatments (Table 2). In the spring, the AUDPC for Bristol was lower than for Speedway regardless of fungicide treatment. In the fall, Bristol had a lower AUDPC than Speedway when plants were sprayed with fungicides, but AUDPC values did not differ between the two cultivars when plants were sprayed with water (fungicide-by-cultivar interaction significant, $P=0.0001$ ). The mean AUDPC value for trellised plants (376.2) was lower than for plants grown without trellising (434.0; trellising main effect significant, $P=0.007$ ).

The percentage of leaf area that was necrotic was rated 51 and 57 days after seeding in spring and fall, respectively. Bristol leaves had less necrotic area $(7.7 \%)$ than Speedway leaves, which had $12.0 \%$ necrotic area $(P<0.0001)$. Necrosis was more severe in the

Table 2. Development of downy mildew on two cultivars of slicing cucumber sprayed or not sprayed in spring and fall experiments

\begin{tabular}{lclcr}
\hline Season & Fungicide $^{\mathbf{w}}$ & Cultivar $^{\mathbf{x}}$ & Final severity (\%) $^{\text {AUDPC }}$ & AU $^{\mathbf{y}}$ \\
\hline Spring & None & Speedway & $81.8 \mathrm{a}^{\mathrm{z}}$ & $1,312 \mathrm{a}$ \\
Spring & None & Bristol & $76.0 \mathrm{a}$ & $938 \mathrm{~b}$ \\
Spring & Yes & Speedway & $24.7 \mathrm{~d}$ & $209 \mathrm{c}$ \\
Spring & Yes & Bristol & $12.9 \mathrm{e}$ & $92 \mathrm{~d}$ \\
Fall & None & Speedway & $58.2 \mathrm{~b}$ & $1,042 \mathrm{ab}$ \\
Fall & None & Bristol & $47.2 \mathrm{c}$ & $882 \mathrm{~b}$ \\
Fall & Yes & Speedway & $23.2 \mathrm{~d}$ & $266 \mathrm{c}$ \\
Fall & Yes & Bristol & $12.5 \mathrm{e}$ & $122 \mathrm{~d}$ \\
\hline
\end{tabular}

${ }^{w}$ The fungicide treatment was chlorothalonil alternated weekly with cyazofamid for seven total applications, and the no-fungicide control treatment was sprayed with water.

${ }^{x}$ Bristol is partially resistant and Speedway is susceptible to cucurbit downy mildew caused by Pseudoperonospora cubensis.

y The area under the disease progress curve (AUDPC) was calculated from the percentage of diseased leaf area.

$\mathrm{z}$ Means within a column with the same letter are not significantly different (Fisher's protected least-significant difference test, $P=0.01$ ).

Table 1. Analysis of variance of disease ratings, yields (number of 24.2-kg cartons per hectare), and price of two cultivars of slicing cucumber sprayed or not sprayed for downy mildew in spring and fall experiments

\begin{tabular}{|c|c|c|c|c|c|c|c|c|c|}
\hline \multirow[b]{3}{*}{ Source of variation } & \multicolumn{9}{|c|}{ Probability of a greater $F$-statistic ${ }^{x}$} \\
\hline & \multirow[b]{2}{*}{ Final severity } & \multirow[b]{2}{*}{ AUDPC ${ }^{y}$} & \multicolumn{5}{|c|}{ Yield $^{\mathbf{z}}$} & \multirow[b]{2}{*}{$\%$ Cull fruit } & \multirow[b]{2}{*}{ Net return } \\
\hline & & & Extra & Large & Small & Marketable & Total & & \\
\hline Season & 0.0001 & 0.36 & 0.0001 & 0.0001 & 0.0001 & 0.0001 & 0.0001 & 0.12 & 0.0001 \\
\hline Fungicide & 0.0001 & 0.0001 & 0.0008 & 0.0001 & 0.0001 & 0.0001 & 0.0002 & 0.014 & 0.0001 \\
\hline Trellis & 0.11 & 0.0069 & 0.46 & 0.80 & 0.0015 & 0.11 & 0.0498 & 0.43 & 0.36 \\
\hline Cultivar & 0.0001 & 0.0001 & 0.0001 & 0.0005 & 0.0001 & 0.0001 & 0.0001 & 0.07 & 0.0001 \\
\hline Season-by-fungicide & 0.0001 & 0.0003 & 0.71 & 0.0001 & 0.21 & 0.83 & 0.28 & 0.43 & 0.68 \\
\hline Season-by-cultivar & 0.0001 & 0.30 & 0.0001 & 0.0043 & 0.0163 & 0.0001 & 0.0003 & 0.85 & 0.0001 \\
\hline Fungicide-by-cultivar & 0.09 & 0.0001 & 0.06 & 0.84 & 0.57 & 0.28 & 0.16 & 0.48 & 0.33 \\
\hline Season-by-fungicide-by-cultivar & 0.44 & 0.53 & 0.0047 & 0.90 & 0.67 & 0.12 & 0.14 & 0.91 & 0.13 \\
\hline
\end{tabular}

${ }^{x}$ Nonsignificant interactions with a $P>0.10$ for all measurements are not shown.

${ }^{y}$ AUDPC $=$ area under the disease progress curve.

${ }^{\mathrm{z}}$ Cucumber fruit were separated by fruit diameter. U.S. Extra No. 1 fruit have a diameter $\leq 6 \mathrm{~cm}$ and length $\geq 15 \mathrm{~cm}$, U.S. No. 1 Large fruit have a diameter $>6 \mathrm{~cm}$ (no length specified), and U.S. No. 1 Small fruit have a diameter $\leq 5 \mathrm{~cm}$ (no length specified) (U.S. Department of Agriculture 2018). 
fall than in the spring, regardless of trellising or fungicide applications (Fig. 1). The season-by-fungicide-by-trellising interaction occurred $(P=0.0061)$ because trellised, nonsprayed plants had a lower percentage of necrosis than nontrellised plants in the spring, but this effect of trellising was not observed on fungicide-treated plants in either season or on nonsprayed plants in the fall (Fig. 1).

In spring, leaf wetness periods were longer on the outsides of the two trellised rows in the split plot than inside the split plot-that is, on the west side of the east row and the east side of the west row (rowby-side interaction significant, $P<0.0001$ ). Leaves were wet for 11.5 and $5.8 \mathrm{~h}$ on the outside and the inside of the trellised plot, respectively. In the fall, however, there was no difference between rows or sides of rows in a trellised plot, and the mean leaf wetness period was $9.3 \mathrm{~h}$. In a nontrellised plot in the spring, mean leaf wetness periods were 9.6 and $11.3 \mathrm{~h}$ on the east and west sides, respectively, of both rows in the plot (side effect significant, $P=0.0385$; row effect not significant, $P=0.28$ ).

In spring, solar radiation did not differ between the east and west sides of a trellised row on the east side of a split plot, with a mean of $13,448 \mu \mathrm{mol} / \mathrm{m}^{2} / \mathrm{s}$ recorded for each 24 -h period between 22 June and 9 July. However, solar radiation was greater $\left(21,160 \mu \mathrm{mol} / \mathrm{m}^{2} / \mathrm{s}\right)$ on the west side of a nontrellised row than on the east side of

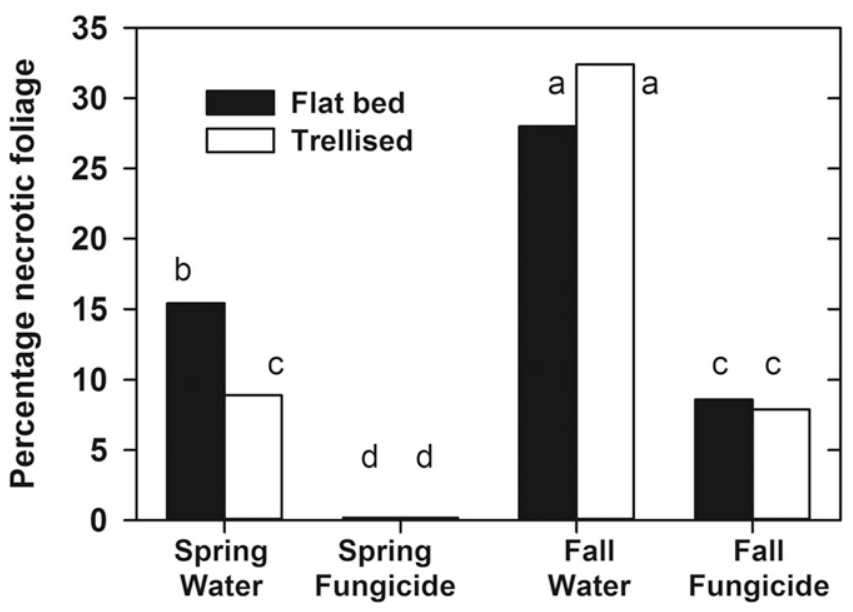

Fig. 1. Combined effects of season, fungicide application, and trellising on necrotic leaf area attributable to downy mildew on slicing cucumber in spring and fall experiments. The season-by-fungicide-by-trellising interaction was significant $(P=0.0061)$. Means with the same letter are not significantly different (Fisher's protected least-significant difference test, $P=0.01$ ). the same row $\left(19,917 \mu \mathrm{mol} / \mathrm{m}^{2} / \mathrm{s}\right)$ between 10 and 17 July $(P=$ 0.0045).

Cultivar significantly affected vine length measured in the nontrellised treatment 6 and 7 weeks after seeding in spring and fall, respectively $(P=0.0002)$. The mean length of Bristol vines was $165.2 \mathrm{~cm}$, whereas Speedway vines were $130.2 \mathrm{~cm}$ long. Season and fungicide application did not affect vine length $(P \geq 0.31)$. Bristol vines grew an average of $0.77 \mathrm{~cm} /$ day more than Speedway vines in the first 45 days after seeding. Bristol vines in the trellised treatments also appeared to be longer than trellised Speedway vines.

Seven yield measurements were analyzed, including weight (expressed as the number of 24.2-kg cartons/ha) of marketable quality fruit of three sizes, cull (nonmarketable) fruit, marketable fruit, total fruit, and percentage of cull fruit. Season and cultivar affected all yield measurements except weight and percentage of cull fruit (significant season-by-cultivar interactions, $P \leq 0.02$ ) (Table 1). Fungicide applications affected all yield measurements except weight of cull fruit $(P \leq 0.01)$. In addition, there was a significant difference between trellising and not trellising for weight of small fruit $(P=$ $0.0015)$ and total fruit $(P=0.05)$. Treatment means of cull fruit were not compared because a significant $(P=0.02)$ four-way interaction occurred among season-fungicide-trellising-cultivar treatments.

Fungicide applications increased marketable and total weights in both seasons, for both cultivars, and for both trellising treatments (fungicide main effect significant, $P \leq 0.0002$ ) (Table 1). Marketable weight from fungicide-treated plants was almost double (93\% greater) than marketable weight from water-treated plants (Table 3). Marketable and total weights also were 55 and $48 \%$ greater, respectively, for Bristol than for Speedway in the spring, but in the fall, yields did not differ significantly between cultivars (season-by-cultivar interactions significant, $P \leq 0.0003$ ). Trellising had no significant effect on marketable yields $(P=0.11)$ but increased total yields by $15 \%$, from 1,217 cartons/ha without trellising to 1,404 cartons/ha with trellising $(P=0.05)$.

When marketable weights were examined by size categories, additional factors and interactions affected weights (Tables 1 and 3). For U.S. Extra No. 1 fruit, there was a three-way interaction of seasonby-fungicide-by-cultivar $(P=0.005)$. In the spring, weight of Bristol fruit did not differ between the fungicide and water treatments, but fruit weight was greater for Speedway treated with fungicide than water. In the fall, weight of Speedway fruit did not differ between fungicide treatments, but weight of Bristol was increased with fungicides compared with water. For U.S. No. 1 Large fruit, weights did not differ between cultivars or fungicide treatments in the fall, but weights differed among all four fungicide-by-cultivar combinations in the spring. Yields were greatest for fungicide-treated Bristol, followed by fungicide-treated Speedway and Bristol not treated with

Table 3. Yield (number of 24.2-kg cartons per hectare) and net returns from two cultivars of slicing cucumber sprayed or not sprayed for downy mildew in spring and fall experiments

\begin{tabular}{|c|c|c|c|c|c|c|c|c|}
\hline \multirow[b]{2}{*}{ Season } & \multirow[b]{2}{*}{ Fungicide $^{\mathbf{u}}$} & \multirow[b]{2}{*}{ Cultivarv $^{\mathbf{v}}$} & \multicolumn{3}{|c|}{ USDA grades of cucumbers by size ${ }^{w}$} & \multirow[b]{2}{*}{ Marketable weight $^{\mathbf{x}}$} & \multirow[b]{2}{*}{ Total weight } & \multirow[b]{2}{*}{ Net return/ha ${ }^{y}$} \\
\hline & & & Extra No. 1 & No. 1 Large & No. 1 Small & & & \\
\hline Spring & Yes & Bristol & $905.4 \mathrm{a}^{\mathrm{z}}$ & $454.3 \mathrm{a}$ & $956.5 \mathrm{a}$ & $2,316.1 \mathrm{a}$ & $2,686.4 \mathrm{a}$ & $31,344 \mathrm{a}$ \\
\hline Spring & Yes & Speedway & $683.3 \mathrm{~b}$ & $328.5 \mathrm{~b}$ & 756.6 a & $1,768.4 \mathrm{~b}$ & $2,126.6 \mathrm{~b}$ & $21,848 \mathrm{~b}$ \\
\hline Spring & None & Bristol & $777.3 \mathrm{ab}$ & $156.5 \mathrm{c}$ & $718.4 \mathrm{ab}$ & $1,652.2 \mathrm{~b}$ & $2,007.7 \mathrm{~b}$ & $19,574 \mathrm{~b}$ \\
\hline Spring & None & Speedway & $297.3 \mathrm{~cd}$ & $33.4 \mathrm{~d}$ & $451.7 \mathrm{c}$ & $782.3 \mathrm{~cd}$ & $1,037.6 \mathrm{c}$ & $4,339 \mathrm{~cd}$ \\
\hline Fall & Yes & Bristol & $341.8 \mathrm{c}$ & $51.3 \mathrm{~d}$ & $496.5 \mathrm{bc}$ & $889.7 \mathrm{c}$ & $1,042.4 \mathrm{c}$ & $7,836 \mathrm{c}$ \\
\hline Fall & Yes & Speedway & 245.1 cde & $31.3 \mathrm{~d}$ & $437.0 \mathrm{c}$ & $713.4 \mathrm{~cd}$ & $863.5 \mathrm{~cd}$ & $4,243 \mathrm{~cd}$ \\
\hline Fall & None & Bristol & $93.4 \mathrm{de}$ & $10.9 \mathrm{~d}$ & $209.1 \mathrm{~d}$ & $313.4 \mathrm{de}$ & $442.1 \mathrm{de}$ & $-2,428 \mathrm{de}$ \\
\hline Fall & None & Speedway & $54.7 \mathrm{e}$ & $2.9 \mathrm{~d}$ & $140.0 \mathrm{~d}$ & $197.5 \mathrm{e}$ & $276.4 \mathrm{e}$ & $-4,731 \mathrm{e}$ \\
\hline
\end{tabular}

u The fungicide treatment was chlorothalonil alternated weekly with cyazofamid for seven total applications, and the no-fungicide control treatment was sprayed with water.

$\checkmark$ Bristol is partially resistant and Speedway is susceptible to cucurbit downy mildew caused by Pseudoperonospora cubensis.

${ }^{\mathrm{w}}$ Cucumber fruit were separated by fruit diameter. U.S. Extra No. 1 fruit have a diameter $\leq 6 \mathrm{~cm}$ and length $\geq 15 \mathrm{~cm}$, U.S. No. 1 Large fruit have a diameter $>6 \mathrm{~cm}$ (no length specified), and U.S. No. 1 Small fruit have a diameter $\leq 5 \mathrm{~cm}$ (no length specified) (U.S. Department of Agriculture 2018).

${ }^{x}$ Marketable weight is the sum of weights of U.S. Extra No. 1, Large, and Small sizes.

y Net return was calculated as (marketable yield $\times$ price) - input costs.

${ }^{\mathrm{z}}$ Means within a column with the same letter are not significantly different (Fisher's protected least-significant difference test, $P=0.01$ ). 
fungicide, whereas Speedway not treated with fungicide had the lowest yield (Table 3). Weights of U.S. No. 1 Small fruit of both cultivars were increased by fungicide applications in both seasons. Cultivar had less of an effect on this size class than on the other size classes, as weight was greater with Bristol than with Speedway only for nonfungicide-treated plants in the spring. In trellised plots, weight of small fruit was increased by $25 \%$, from 463 cartons/ha without trellising to 579 cartons/ha with trellising.

Most cull fruit were misshapen, too curved to be considered marketable. Fungicide applications reduced the percentage of cull fruit from 27.1 to $15.9 \%(P=0.014)$. Season, trellising, and cultivar did not affect the percentage of cull fruit (Table 1).

Disease ratings during the second half of the seasons were significantly negatively correlated with weights of total and marketable fruit and percentage of cull fruit but not weight of cull fruit (Table 4). When correlations were calculated with data from both seasons, Pearson correlation coefficients were highest with percentage necrotic foliage and second highest with disease severity at 48 or 51 days after seeding in fall and spring, respectively (DS 4/5) (Fig. 2). When correlations were calculated separately for each season, disease severity and AUDPC also were significantly negatively correlated with yields (data not shown). Disease severity ratings during the first half of the seasons were not correlated with yields (data not shown).

Results for prices of harvested fruit (data not shown) and net returns were similar to the results for marketable weight (Table 3). Prices and net returns were greater for the fungicide treatment than the water control treatment $(P=0.0001)$. In addition, prices and net returns were greater for Bristol than for Speedway in the spring but not in the fall (season-by-cultivar interaction significant, $P=0.0001$ ). The treatment with the overall highest return was fungicide-treated Bristol grown in the spring, whose net return was estimated to be $>\$ 30,000 /$ ha. Speedway grown in the spring without fungicides had a lower price and net return than Speedway grown with fungicides or Bristol grown with or without fungicides. Net returns were negative in the fall for both cultivars not treated with fungicide.

\section{Discussion}

Of the three management techniques examined in this study, fungicides had the largest effects on downy mildew and yields of slicing

Table 4. Pearson correlation coefficients between disease and yield measurements

\begin{tabular}{lrrrrr}
\hline & \multicolumn{5}{c}{ Yield } \\
\cline { 2 - 6 } & DS 4/5 & DS 5/6 & DS 6/7 & Necrosis $^{\mathbf{v}}$ & AUDPC $^{\mathbf{w}}$ \\
\hline Total weight $^{\mathrm{x}}$ & $-0.6649^{\mathrm{y}}$ & -0.5559 & -0.5316 & -0.8283 & -0.4746 \\
& 0.0050 & 0.0253 & 0.0341 & 0.0001 & 0.0633 \\
Marketable weight $^{\mathrm{z}}$ & -0.6908 & -0.5855 & -0.5631 & -0.8355 & -0.5094 \\
& 0.0030 & 0.0172 & 0.0231 & 0.0001 & 0.0439 \\
Extra No. 1 weight & -0.6331 & -0.5038 & -0.4712 & -0.8006 & -0.4294 \\
& 0.0085 & 0.0466 & 0.0654 & 0.0002 & 0.0969 \\
No. 1 Large weight & -0.6442 & -0.5903 & -0.6005 & -0.7196 & -0.5512 \\
& 0.0071 & 0.0161 & 0.0139 & 0.0017 & 0.0269 \\
No. 1 Small weight & -0.7221 & -0.6223 & -0.5941 & -0.8694 & -0.5293 \\
& 0.0016 & 0.0100 & 0.0152 & $<0.0001$ & 0.0350 \\
Cull weight & -0.4529 & -0.3310 & -0.2964 & -0.7177 & -0.2236 \\
& 0.0782 & 0.2105 & 0.2649 & 0.0017 & 0.4052 \\
Percentage cull & 0.8352 & 0.7860 & 0.7465 & 0.8018 & 0.7484 \\
weight & & & & & \\
& 0.0001 & 0.0003 & 0.0009 & 0.0002 & 0.0009 \\
\hline
\end{tabular}

${ }^{\mathrm{u}}$ DS is the percentage of disease severity at the specified rating number in fall and spring, respectively.

$v$ The percentage of necrosis rated 51 and 51 days after seeding in spring and fall, respectively, is shown.

${ }^{w}$ The area under the disease progress curve (AUDPC) was calculated from severity ratings.

${ }^{x}$ Total weight is the sum of marketable and cull weights.

y The Pearson correlation coefficient is shown in the top row; the probability that the absolute value of the correlation coefficient is $>0$ is shown in the bottom row.

${ }^{\mathrm{z}}$ Marketable weight is the sum of weights of U.S. Extra No. 1, Large, and Small sizes. cucumber, effects that largely were consistent across the two seasons. Fungicide applications decreased final disease severity and AUDPC, increased yields of all sizes of fruit, decreased the percentage of cull fruit, and increased prices and net returns. There was no fungicideby-trellis interaction because fungicide applications reduced severity of downy mildew on trellised as well as nontrellised plants. Similar results were reported from Ohio, where four fungicide programs were tested on trellised and nontrellised plants (Baysal-Gurel et al. 2014, 2015). For the current study, chlorothalonil (FRAC code M05) and cyazofamid (FRAC code 21) were chosen as the fungicide treatment because of their low input costs and consistent effectiveness when used preventatively against cucurbit downy mildew on slicing cucumber (Baysal-Gurel et al. 2015; Keinath 2016; Vallad et al. 2015, 2016). Chlorothalonil is a multisite contact chloronitrile fungicide, and cyazofamid is a systemic cyano-imidazole fungicide in the quinone inside inhibitor group. Based on other experiments with pickling cucumber, oxathiapiprolin (FRAC code 49) was the only fungicide among eight to 26 fungicides tested that decreased disease severity compared with cyazofamid (Adams and QuesadaOcampo 2016, 2017; Adams et al. 2015; Trueman 2016). Fruit weight was greater with oxathiapiprolin than with cyazofamid in three of the experiments, whereas yield did not differ between these two fungicides in the fourth experiment. Oxathiapiprolin also increased yields compared with chlorothalonil in all four experiments, and cyazofamid increased yields over chlorothalonil in two experiments. Another advantage to applying cyazofamid to cucurbits is that it has a lower toxicity to bees than other downy mildew fungicides (Eshenaur et al. 2015). To minimize the potential effects of fungicides on pollinators that visit cucumber flowers, a different downy mildew fungicide could be substituted for chlorothalonil, since it has a higher toxicity to bees than other downy mildew fungicides.

The resistant cultivar Bristol usually had less severely diseased leaves than the genetically related, susceptible cultivar Speedway. Bristol had higher marketable weights of all sizes of slicing cucumbers in the spring but not in the fall season. In a fall field experiment on Long Island, New York, in which mating type A1 likely was present, Bristol was one of the three most resistant cultivars tested, whereas Speedway was the second most susceptible (McGrath et al. 2018; Ojiambo et al. 2019). Bristol not treated with fungicide had lower AUDPC values, but not lower final disease severity, than Speedway. Similar results were observed for AUDPC and final disease severity with these two cultivars in the spring in South Carolina. In New York, marketable weights were greater for Bristol than for

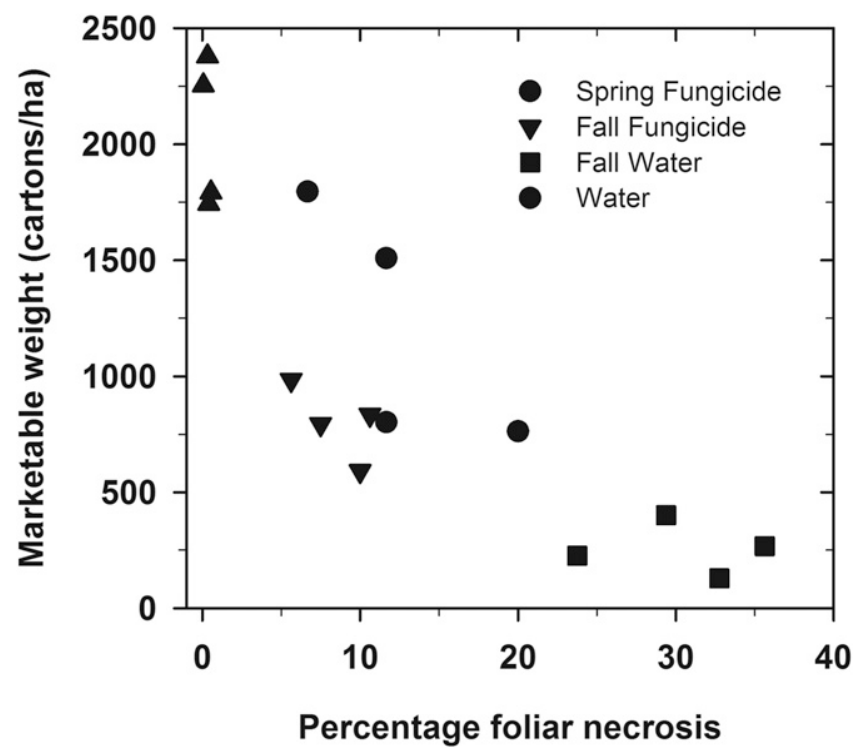

Fig. 2. Relationship showing a significant $(P=0.0001)$ negative correlation between the percentage of foliar necrosis and marketable weight. Foliar necrosis was rated at 51 and 57 days after seeding in spring and fall, respectively. 
Speedway in an epidemic that started 2 weeks after transplanting (McGrath et al. 2018). Yields of nonsprayed plants were much lower in New York, where the epidemic began sooner than in South Carolina, even though the current experiments were initiated near the end of the recommended planting date for cucumber in South Carolina to increase the chance that downy mildew was present during the harvest period, based on first detection dates in Charleston during the past decade (Kemble et al. 2019; Ojiambo et al. 2019). In a fall field trial in Georgia in which unspecified fungicides were applied to manage downy mildew, Bristol also had lower severity of downy mildew than the susceptible cultivar Darlington and seven other cultivars. Bristol had a greater marketable yield than Darlington and three other cultivars (Coolong et al. 2015). It is possible that the greater vigor of Bristol vines than Speedway vines contributed to the better yield of Bristol compared with Speedway.

Trellised plants had a lower mean AUDPC than nontrellised plants. In the spring, the less severe necrosis on nonfungicidetreated, trellised plants may have contributed to lower AUDPC values for the trellised treatment. In two experiments in Ohio, neither final severity of downy mildew nor AUDPC was affected by trellising (Baysal-Gurel et al. 2014, 2015). Although some differences were observed in leaf wetness periods within trellised and nontrellised treatments, modifications of environment were not great enough to impact downy mildew development. Infection of cucumber by sporangia of $P$. cubensis requires $3 \mathrm{~h}$ of leaf wetness at 15 and $25^{\circ} \mathrm{C}$ or $2 \mathrm{~h}$ at $20^{\circ} \mathrm{C}$ (Neufeld and Ojiambo 2012). Leaf wetness periods on trellised plants were $>5 \mathrm{~h}$, well above the threshold for infection between 10 and $30^{\circ} \mathrm{C}$. In the current experiment, the increase in weight of small fruit with trellising did not increase the weight of marketable fruit produced by trellised plants. Since trellising had no effect on marketable yields, trellising is not a recommended management practice for downy mildew.

AUDPC showed a fungicide-by-cultivar interaction, an indication of synergy between fungicides and resistance, because the combination of fungicide applications and cultivar resistance was more effective than predicted when the two management techniques were applied together (Ritchie et al. 2018). AUDPC on fungicide-treated Bristol was significantly lower than on nonsprayed Bristol or fungicide-treated Speedway. Fungicide applications were equally effective on the two cucumber cultivars, as fungicides reduced AUDPC by $80 \%$ on Bristol and $88 \%$ on Speedway. The effects of cultivar resistance, however, were proportionally greater in the presence of fungicide than on nonsprayed plants, as resistance reduced AUDPC by $22 \%$ on nonsprayed plants but by $55 \%$ on sprayed plants. A fungicide-by-cultivar interaction also was observed for AUDPC when two breeding lines resistant to downy mildew were compared with the susceptible cultivar Dasher II in a field experiment in New York. Holdsworth and Mazourek (2014) interpreted the interaction as demonstrating a larger effect of fungicides on the susceptible cultivar than on the resistant lines. In Ohio, no evidence of synergy between fungicides and resistance was observed with SV4719CS, a cultivar partially resistant to downy mildew. SV4719CS had a lower AUDPC value compared with Speedway when the cultivars were not treated with fungicides, but AUDPC values did not differ between the two cultivars when fungicides were applied (Schoenhals and Jasinski 2016). In Virginia, no fungicide-by-cultivar interaction was observed when eight cucumber cultivars were sprayed zero, two, or four times for downy mildew (Cooper et al. 2012). For late blight of potato, another foliar disease caused by an oomycete, the effects of partial cultivar resistance and protectant fungicide applications on AUDPC also were additive, not synergistic (Fry 1978).

Contrary to the results with AUDPC, little evidence was seen for a synergy between fungicide and cultivar resistance for most yield measurements in the current study, as the fungicide-by-cultivar interactions were not significant. The effects of fungicide and cultivar resistance appeared to be additive in the spring season. Fungicide applications increased mean marketable weight by 686 cartons/ha, cultivar resistance in Bristol increased weight by 709 cartons/ha, and fungicides and cultivar resistance applied together increased weight by 1,534 cartons/ha. In Virginia and North Carolina, significant fungicide-by-cultivar interactions were reported for total weight of slicing and pickling cucumber, respectively. In Virginia, yield of the partially resistant cultivar Tasty Green did not differ between a low input program with two fungicide applications and a program with four applications, but yields for seven other cultivars were lower with fewer fungicide applications (Cooper et al. 2012). In North Carolina, weight of the moderately resistant cultivar M21 treated with only mancozeb was similar to weight of the highly susceptible cultivar Wisconsin SMR-18 treated with famoxadone, cymoxanil, and propamocarb (Call et al. 2013). Call et al. (2013) considered fungicides to be the more important factor in determining yield with an additional additive effect of cultivar resistance. These fungicide-by-cultivar interactions, however, suggest that the number of fungicide applications could be reduced with certain cultivars of slicing cucumber partially resistant to downy mildew.

In the spring, Bristol not treated with fungicide had yields of U.S. Extra No. 1, U.S. No. 1 Small, and marketable fruit equivalent to yields of Speedway treated with fungicide. Thus, Bristol may be a cultivar that can be grown successfully in the spring with organic disease management, such as applications of copper hydroxide against downy mildew (Marine et al. 2016; McGrath and Sexton 2017). A season-by-cultivar interaction was observed for all yield measurements, because Bristol did not increase yields in the fall season as it did in the spring. However, the consistently lower disease severity on Bristol in both seasons is a good reason to choose Bristol or another cultivar that is partially resistant to cucurbit downy mildew for production in either season. Environmental conditions in 2017 during the spring experiment were similar to the average temperature and rainfall in Quincy, Florida, one of three main cucumberproducing areas in Florida, the state that produces the most slicing cucumbers in the United States (Aerts and Mossler 2003). Thus, Bristol may perform similarly well in the spring in other southeastern production areas.

Epstein (2014) states that IPM practices have not substantially reduced the application of pesticides to food crops in the United States or elsewhere in the world. The current study illustrates one reason for the continued reliance on fungicides for disease management in certain pathosystems - namely, a limited number of cucumber cultivars with resistance to downy mildew that produce a profitable yield, particularly in the fall (Call et al. 2013). With continued demand for locally produced vegetables, not all cucumber production can be shifted to areas with environments less conducive to downy mildew than the eastern United States. For example, South Carolina consumers were willing to pay an average of $27 \%$ more for fruit or vegetables grown in the state (Carpio and Isengildina-Massa 2009). Fungicides remain a necessary component of integrated management of downy mildew on slicing cucumber, whether $P$. cubensis mating type A1 or a mixture of mating types A1 and $\mathrm{A} 2$ is present and whether older cultivars resistant to A2 or newer cultivars resistant to $\mathrm{A} 1$ and $\mathrm{A} 2$ are grown.

\section{Acknowledgments}

I thank V. B. DuBose, C. D. Conrad, and C. S. Burtt for technical assistance and Bayer for providing seed.

\section{Literature Cited}

Adams, M. L., Parada, C. H., and Quesada-Ocampo, L. M. 2015. Evaluation of fungicides for control of downy mildew on cucumber, Kinston I 2014. Plant Dis. Manage. Rep. 9:V086.

Adams, M. L., and Quesada-Ocampo, L. M. 2016. Evaluation of fungicides for control of downy mildew on cucumber, Kinston 2015. Plant Dis. Manage. Rep. 10:V081.

Adams, M. L., and Quesada-Ocampo, L. M. 2017. Evaluation of fungicides for control of downy mildew on cucumber, Kinston 2016. Plant Dis. Manage. Rep. 11:V097.

Aerts, M., and Mossler, M. 2003. Crop profile for cucumbers in Florida. Southern Integrated Pest Management Center. https://ipmdata.ipmcenters.org/documents/ cropprofiles/FLcucumber2003.pdf

Baysal-Gurel, F., Mera, J., and Miller, S. A. 2014. Evaluation of fungicides and trellising for the control of downy mildew and Phytophthora fruit rot of cucumber, 2013. Plant Dis. Manage. Rep. 8:V176.

Baysal-Gurel, F., Mera, J., and Miller, S. A. 2015. Evaluation of fungicides and production methods for the control of downy mildew and Phytophthora fruit rot of cucumber, 2014. Plant Dis. Manage. Rep. 9:V054. 
Brent, K. J., and Holloman, D. W. 2007. Fungicide resistance in crop pathogens: How can it be managed? FRAC Monograph No. 1, 2nd ed. Fungicide Resistance Action Committee, CropLife International. http://www.frac.info/docs/default-source/ publications/monographs/monograph-1.pdf?sfvrsn=769d419a_8

Call, A. D., Wehner, T. C., Holmes, G. J., and Ojiambo, P. S. 2013. Effects of host plant resistance and fungicides on severity of cucumber downy mildew. HortScience 48:53-59.

Carpio, C., and Isengildina-Massa, O. 2009. Consumer willingness to pay for locally grown products: The case of South Carolina. Agribusiness 25:412-426.

Clemson Cooperative Extension. 2018. Spring cucumber-for fresh marketirrigated. https://www.clemson.edu/extension/agribusiness/enterprise-budget/ melons-vegetables.html

Colucci, S. J., and Holmes, G. J. 2010. Downy mildew of cucurbits. Plant Health Instructor.

Coolong, T., Dutta, B., and Sanders, H. 2015. Evaluation of yield and downy mildew resistance in cucumber in Georgia, 2014. Plant Dis. Manage. Rep. 11:V149.

Cooper, J. G., Rideout, S. L., Waldenmaier, C. M., Kellam, A. N., Blodgett, M. K., and Custis, J. T., Jr. 2012. Evaluation of host-resistance and fungicides to manage downy mildew of slicer-type cucumbers, 2011. Plant Dis. Manage. Rep. 6:V053.

Epstein, L. 2014. Fifty years since Silent Spring. Annu. Rev. Phytopathol. 52: $377-402$.

Eshenaur, B., Grant, J., Kovach, J., Petzoldt, C., Degni, J., and Tette, J. 2015. Environmental impact auotient: A method to measure the environmental impact of pesticides. New York State Integrated Pest Management Program, Cornell Cooperative Extension, Cornell University. http://nysipm.cornell.edu/ publications/EIQ

Fry, W. 1978. Quantification of general resistance of potato cultivars and fungicide effects for integrated control of potato late blight. Phytopathology 68: 1650-1655.

Hausbeck, M. 2017. Downy mildew. Pages 56-59 in: Compendium of Cucurbit Diseases and Pests, 2nd ed. A. P. Keinath, W. M. Wintermantel, and T. A. Zitter, eds. American Phytopathological Society, St. Paul, MN.

Holdsworth, W. L., and Mazourek, M. 2014. Efficacy of genetic resistance and fungicide for control of downy mildew on cucumber, 2013. Plant Dis. Manage. Rep. 8:V285.

Holmes, G. J., Ojiambo, P. S., Hausbeck, M. K., Quesada-Ocampo, L., and Keinath, A. P. 2015. Resurgence of cucurbit downy mildew in the United States: A watershed event for research and extension. Plant Dis. 99:428-441.

Kanetis, L., Holmes, G. J., and Ojiambo, P. S. 2010. Survival of Pseudoperonospora cubensis sporangia exposed to solar radiation. Plant Pathol. 59:313-323.

Keinath, A. P. 2016. Utility of a cucumber plant bioassay to assess fungicide sensitivity in Pseudoperonospora cubensis. Plant Dis. 100:490-499.

Kemble, J. M., Meadows, I. M., Jennings, K. M., and Walgenbach, J. F., eds. 2019. Southeastern U.S. 2019 Vegetable Crop Handbook. https://www. growingproduce.com/southeasternvegetablecrophandbook/

Marine, S. C., Newark, M. J., Korir, R. C., and Everts, K. L. 2016. Evaluation of rotational biopesticide programs for disease management in organic cucurbit production. Plant Dis. 100:2226-2233.

McGrath, M. T., Menasha, S. R., and Sexton, Z. F. 2018. Evaluation of cucumber cultivars resistant to downy mildew, 2017. Plant Dis. Manage. Rep. 12:V069.

McGrath, M. T., and Sexton, Z. F. 2017. Efficacy of fungicides for managing downy mildew organically in cucumber, 2016. Plant Dis. Manage. Rep. 11: V023.

Neufeld, K. N., and Ojiambo, P. S. 2012. Interactive effects of temperature and leaf wetness duration on sporangia germination and infection of cucurbit hosts by Pseudoperonospora cubensis. Plant Dis. 96:345-353.
Ojiambo, P. S., Britton, W., and Keever, T. 2019. Annual epidemic histories. Cucurbit Downy Mildew Forecasting. http://cdm.ipmpipe.org/node/107

Ojiambo, P. S., Holmes, G. J., Britton, W., Keever, T., Adams, M. L., Babadoost, M., Bost, S. C., Boyles, R., Brooks, M., Damicone, J., Draper, M. A., Egel, D. S., Everts, K. L., Ferrin, D. M., Gevens, A. J., Gugino, B. K., Hausbeck, M. K., Ingram, D. M., Isakeit, T., Keinath, A. P., Koike, S. T., Langston, D., McGrath, M. T., Miller, S. A., Mulrooney, R., Rideout, S., Roddy, E., Seebold, K. W., Sikora, E. J., Thornton, A., Wick, R. L., Wyenandt, C. A., and Zhang, S. 2011. Cucurbit downy mildew ipmPIPE: A next generation web-based interactive tool for disease management and extension outreach. Plant Health Prog. https://doi.org/10.1094/PHP-2011-0411-01-RV

Olaya, G., Kuhn, P., Hert, A., Holmes, G., and Colucci, S. 2009. Fungicide resistance in cucurbit downy mildew. (Abstr.). Phytopathology 99:S171.

Ritchie, F., Bain, R. A., Lees, A. K., Boor, T. R. W., and Paveley, N. D. 2018. Integrated control of potato late blight: Predicting the combined efficacy of host resistance and fungicides. Plant Pathol. 67:1784-1791.

Schoenhals, J., and Jasinski, J. 2016. Evaluation of control measures for downy mildew on cucumber in Ohio, 2015. Plant Dis. Manage. Rep. 10:V071.

Sitterly, W. R. 1972. Breeding for disease resistance in cucurbits. Annu. Rev. Phytopathol. 10:471-490.

Sydorovych, O., Louws, F., and Gunter, C. 2012. Cost of producing, harvesting and marketing field grown tomatoes in the southeastern United States. North Carolina State University Agricultural and Resource Economics. https:// cals.ncsu.edu/are-extension/wp-content/uploads/sites/27/2018/03/Tomato_ Budget_Program_2012 conventional_field locked_full.pdf

Thomas, A., Carbone, I., Choe, K., Quesada-Ocampo, L. M., and Ojiambo, P. S 2017a. Resurgence of cucurbit downy mildew in the United States: Insights from comparative genomic analysis of Pseudoperonospora cubensis. Ecol Evol. 7:6231-6246.

Thomas, A., Carbone, I., Lebeda, A., and Ojiambo, P. S. 2017b. Virulence structure within populations of Pseudoperonospora cubensis in the United States. Phytopathology 107:777-785.

Thomas, A., Neufeld, K. N., Seebold, K. W., Braun, C. A., Schwarz, M. R., and Ojiambo, P. S. 2018. Resistance to fluopicolide and propamocarb and baseline sensitivity to ethaboxam among isolates of Pseudoperonospora cubensis from the eastern United States. Plant Dis. 102:1619-1626.

Trueman, C. L. 2016. Evaluation of fungicides for management of downy mildew in cucumbers, 2015. Plant Dis. Manage. Rep. 10:V024.

University of California Statewide Integrated Pest Management Program. 2013 What is integrated pest management (IPM)? http://www2.ipm.ucanr.edu/ What-is-IPM/

U.S. Department of Agriculture. 2018. United States standards for grades of cucumbers. https://www.ams.usda.gov/sites/default/files/media/CucumberStandards.pdf

Vallad, G. E., Hughes, B., Kalb, S., Adkison, H., and Willis, R. 2016. Evaluation of selected fungicides for management of downy mildew on cucumber, fall 2015. Plant Dis. Manage. Rep. 10:V126.

Vallad, G. E., Hughes, B., Kalb, S., Adkison, H., Willis, R., Riniker, A., and KC A. N. 2015. Evaluation of selected fungicides for management of downy mildew on cucumber, spring 2014. Plant Dis. Manage. Rep. 9:V069.

Wang, Y., VandenLangenberg, K., Wen, C., Wehner, T. C., and Weng, Y. 2018 QTL mapping of downy and powdery mildew resistances in PI 197088 cucumber with genotyping-by-sequencing in RIL population. Theor. Appl Genet. 131:597-611.

Wehner, T. C. 2019. Cucumber trials: Data correction factors. Cucurbit Breeding at NC State. http://cucurbitbreeding.com/cucumber-breeding/cucumber-trials-datacorrection-factors/ 